\title{
Taxonomic aspects and coning ecology of Cycas circinalis L. (Cycadales: Cycadaceae), a threatened species of India
}

\author{
A.J. Solomon Raju ${ }^{1} \&$ N. Govinda Rao ${ }^{2}$ \\ 1,2 Department of Environmental Sciences, Andhra University, Visakhapatnam, Andhra Pradesh 530003, India \\ Email: ${ }^{1}$ ajsraju@yahoo.com (corresponding author), govindnidigattu@gmail.com
}

\begin{abstract}
Cycas circinalis is Red Listed Endangered species. It is a tropical dry deciduous dioecious shrub confined to the Western Ghats and its adjacent regions. It reproduces asexually and sexually. Asexual mode exists in male plants only but further studies are suggested for confirmation. In the asexual mode, bulbils arise as offshoots of the stem; they germinate either on the same plant to produce additional shoots or fall off to germinate and produce new plants. Sexual reproduction involves cone and seed production. The sex of the plant is identifiable only during the coning phase. The plant is typically anemophilous and it is highly effective for optimal seed set. The cones of both sexes show weak thermogenesis and odour production during maturation process and these two processes have absolutely no role in pollination. Coning and leaf flushing events occur in quick succession in both sexes. Seed set is optimal and the seed coat is four-layered consisting of sarcotesta, sclerotesta, a thick layer of spongy tissue and a thin membranous jacket enclosing the female gametophyte tissue; the spongy layer is important to cause floatation in water for seed dispersal which occurs during the rainy season.
\end{abstract}

Keywords: Anemophily, bulbil reproduction, coning phenology, Cycas circinalis, leaf phenology.

Cycas circinalis is an Endagnered (IUCN Red List: Varghese et al. 2009) deciduous Indian endemic gymnosperm species restricted to the Western Ghats

Date of publication (online): 26 January 2011

Date of publication (print): 26 January 2011

ISSN 0974-7907 (online) | 0974-7893 (print)

Editor: Cleofas R. Cervancia

\section{Manuscript details:}

Ms \# 02372

Received 28 December 2009

Final received 10 April 2010

Finally accepted 24 December 2010

Citation: Raju, A.J.S. \& N.G. Rao (2011). Taxonomic aspects and coning ecology of Cycas circinalis L. (Cycadales: Cycadaceae), a threatened species of India. Journal of Threatened Taxa 3(1): 1425-1431.

Copyright: () A.J. Solomon Raju \& N.G. Rao 2011. Creative Commons Attribution 3.0 Unported License. JoTT allows unrestricted use of this article in any medium for non-profit purposes, reproduction and distribution by providing adequate credit to the authors and the source of publication.

Acknowledgement: We thank Dr. K. Henry Jonathan, for field assistance during the course of the work.

OPEN ACCESS I FREE DOWNLOAD (C) (i) (4) and hills of the southern peninsular, as far north-east as Chennai, in the states of Kerala, Karnataka, Tamil Nadu and Maharashtra (Hill 1995; Hill et al. 2003). The species name got its origin from the Latin word "circinus" meaning inrolled leaflets in developing leaves. Good populations exist in a number of national parks and forest reserves despite the use of this plant in some pockets of its distribution. It typically occurs in fairly dense, seasonally dry, scrubby woodlands in hilly areas and is suggested to be an adaptable species with colonies extending from rocky hill outcrops down to coastal habitats at sea level (Singh 1993; Lindstrom \& Hill 2007). This species is commonly cultivated as a garden ornamental plant in the Eastern Ghats region. The clumps of $C$. circinalis are exploited for their feathery leaves which are sold in the local flower markets; the plants are also cut by the locals to remove the pith from the stem due to its medicinal properties. In Kerala, the locals, however, do not practice the devastating cutting of stems for medicine. Further, there are very large populations along the coast and have been integrated within local villages, hence, they are left undisturbed (Lindstrom \& Hill 2007). Cycas circinalis has close resemblances to another Data Deficient species, C. sphaerica; this led Rao \& Sreeramulu (1986) to document C. sphaerica as $C$. circinalis in the flora of Srikakulam where $C$. sphaerica occurs. Reddy et al. (2007) distinguished these two species on the basis of certain female cone characteristics.

Hilletal.(2003)reported that C.circinalis is suffering from poor reproduction due to loss of pollinators. They have also mentioned that experimental studies are lacking in Asian cycads and very little is known about pollination in the genus Cycas. Some Asian cycads have been considered to be entomophilous due to the release of volatile compounds from their cones 
during maturation process, and the involvement of insect groups in the pollination of other cycads. With this backdrop, $C$. circinalis has been investigated for its pollination ecology and the same is described and explained in the light of relevant information.

\section{Materials and Methods}

Cycas circinalis is a tropical dry deciduous shrub. Seven male and three female plants cultivated in Andhra University and in other places of Visakhapatnam, Andhra Pradesh, were used for the study during 2008-2009. The average temperature during the summer season is $38.8^{\circ} \mathrm{C}$. Plant characteristics, leaf and coning phenology were carefully observed. Leaf characteristics and leaflet number per leaf were also recorded. The male and female cones were examined for heat production during the maturation period; the temperature within and outside the cone before, during and after pollen shedding in male cone and during maturation of female cone was measured by using a thermometer. In male cones, the arrangement and number of sporophylls, and the number of sori consisting of microsporangia were recorded. The pollen output per microsporangia/sporophyll/cone and the pollen grain characteristics were recorded by following the protocol suggested by Dafni et al. (2005). Pollen protein content per sporophyll/cone was also estimated as per the method prescribed by Lowry et al. (1951). In female cones, the number of sporophylls per cone and the number of ovules per sporophyll/cone were recorded. Ten ovules were used to record the ovule characteristics. The pollen grain characteristics were examined for anemophilous traits. The plant characteristics were also considered to evaluate the efficiency of anemophily. Seed set in all the three female plants was recorded. The duration of seed maturation was also observed by following female cones periodically until maturation. Seed characteristics were examined in detail. Further, one hundred offshoots of stem "bulbils" were followed to determine the success of germination and production of new shoots right on the stem or new plants after detachment.

\section{Results}

C. circinalis is a palm-like shrub with an erect solitary stem up to $8 \mathrm{~m}$ with a diameter of up to $30 \mathrm{~cm}$. The plant consists of a slightly swollen stem covered with thick bark which in turns bears persistent leaf bases. The apex of the stem is crowned with 20-25 pinnately compound leaves each of which consists of 62-135 pairs of leaflets. It is dioecious but plant sex can be determined only during cone formation. Both male and female plants show coning episode at the same time during April-June. The coning plants are leafless prior to cone production. In male plants, the number of cones produced is equivalent to the number of off-shoots, while female plants without off-shoots produced a single cone (Image $1 \mathrm{a}, \mathrm{b}$ ). Further, a male shoot rarely produces two cones at a time (Image 1c). Male cones are shortly stalked, compact, narrowly ovoid woody structure, light brown to light orange in colour, $42.11 \pm 3.12 \mathrm{~cm}$ long and $14-16 \mathrm{~cm}$ diameter. A cone consists of $729 \pm 44$ sporophylls which are arranged spirally around a central $35.4 \pm 0.86$ long axis. All the sporophylls are fertile except a few at its basal and apical parts. Each sporophyll is a woody, brown coloured, $5.22 \pm 0.44 \mathrm{~cm}$ long and $2-3 \mathrm{~cm}$ wide, and more or less horizontally flattened structure with a narrow base and an expanded upper portion. The upper part is terminated with a prominent $1.86 \pm 0.34$ $\mathrm{cm}$ long prominent apical spine. The narrow basal part is attached to the cone axis. Each sporophyll contains an adaxial surface and an abaxial surface. The adaxial surface does not bear microsporangia while the abaxial surface bears microsporangia up to the expanded part of the sporophyll (Image 1d). The sporangia occur in groups of 3 or 4; each such group represents a 'sorus' (Image 1e). Each sporophyll contains 934.4 \pm 143.93 microsporangia; each sporangium contains $19,875 \pm 4,023$ pollen grains and the total number of pollen grains are 1,85,71,200 $\pm 35,66,377$. Each male cone contains $1354,21,19,040 \pm 260,06,01,846$ pollen grains. The pollen grains are light yellow, powdery, spheroidal, $24.9 \mu \mathrm{m}$ in size, unicellular and uninucleate surrounded by a thick exine and thin intine (Image 1 $\mathrm{f}-\mathrm{h})$. The total protein content in all the microsporangia of a microsporophyll is $8.42 \mathrm{mg}$ and per cone is $6.14 \mathrm{~g}$.

Male cones produce heat at maturation during which they elongate loosening the sporophylls. Just before pollen shedding, the temperature is $34.2 \pm 0.63$ ${ }^{\circ} \mathrm{C}$ within the cone and $33.4 \pm 1.13{ }^{\circ} \mathrm{C}$ outside the cone. During pollen shedding, it is $35.8 \pm 0.86{ }^{\circ} \mathrm{C}$ within the cone and $33.7 \pm 0.75^{\circ} \mathrm{C}$ outside the cone. After pollen shedding, it is $34.4 \pm 0.67{ }^{\circ} \mathrm{C}$ within the cone and $33.5 \pm 0.49^{\circ} \mathrm{C}$ outside the cone. The temperature 

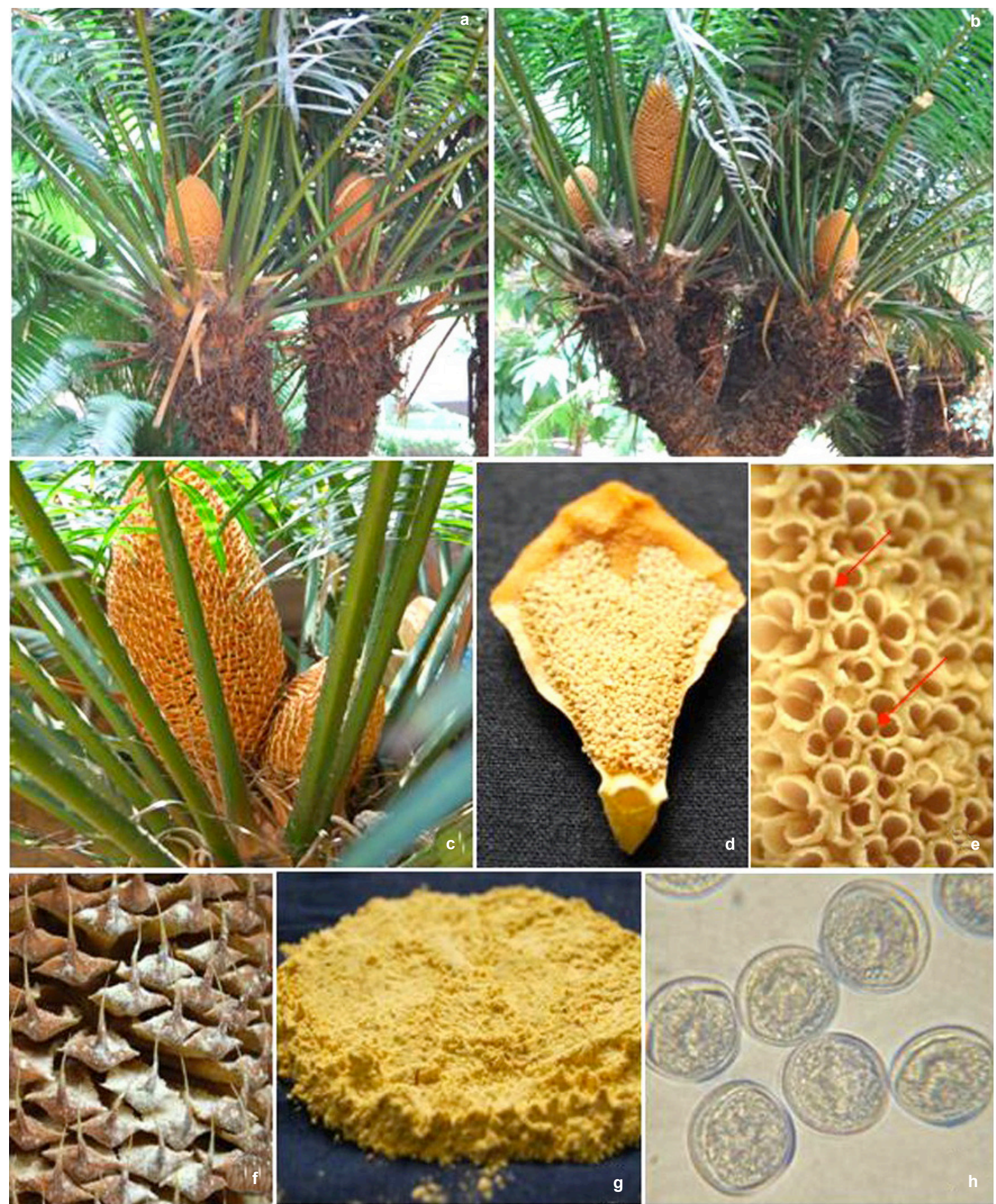

Image 1. Cycas circinalis

a \& b - Single male cone per each branch of male plant; c - Two male cones per branch in male plant; $d$ - Microsporophyll with sporangia; e - Dehisced sori; f \& g - Dry, powdery pollen; $\mathrm{h}$ - Pollen grains

regime during cone maturation process shows that the endogenous heat production caused a rise of $1.6^{\circ} \mathrm{C}$ against the ambient temperature. At this temperature the cone produced a mild foetid odour which could be detected by smell $10 \mathrm{~m}$ away; after pollen shedding, the strength of the odour gradually diminished over 
a period of about five days. With the mild odour and protein-rich pollen, the cones could not attract any insect species before, during and after pollen shedding (Image 2a). The pollen being powdery falls off and accumulates on the adaxial side of the sporophylls which are situated below and it is also scattered all over the stem due to wind activity. The pollen-shed male cones gradually bend to one side and remain in place for about one year. The cones in this position make way for the emergence of new leaves at the top of the stem (Image 2b). The rachis of a very young leaf is circinate with coiled leaflets; the leaflets are sessile, semi-glossy, gradually expand into lanceolate structures with flat margins and softly acute apex arranged on both sides of the rachis in opposite manner. Each leaf has 55-90 pairs of light green leaflets. The new leaves develop fully within three weeks and fall off during late winter.

Female cones represent a cluster ofmegasporophylls and emerge at the apex of the stem. Each cone consists of $48.66 \pm 18.44$ megasporophylls which are orange, triangular, tomentose and $25.34 \pm 5.46 \mathrm{~cm}$ long. Female cones do not produce any detectable odour during their maturation process. Each sporophyll is differentiated into a basal stalk and an upper pinnate flat lamina which is lanceolate and regularly dentate with about 30 pungent lateral 2-3 $\mathrm{mm}$ long spines which are quite distinct from $12-31 \mathrm{~mm}$ long and 3-5 mm wide apical spine. Ovules are formed on the lateral sides of the stalk and their number varies from 2 to 12 . One-ovuled megasporophylls are $0.5 \%$, twoovuled $1 \%$, three-ovuled $0.5 \%$, four-ovuled $2.5 \%$, five-ovuled $7.5 \%$, six-ovuled $44 \%$, seven-ovuled $13 \%$, eight-ovuled $27 \%$ and nine-ovuled $4 \%$. Ovules are sessile, orthotropous, creamy white, sub-globose and unitegmic. Integument remains fused with the body of the ovule except at the apex of the nucellus where it forms nucellar beak and a micropyle opening. The mature cones open slightly exposing the ovules at pollination. The number of ovules is 270 in plant 1 , 157 in plant 2 and 315 in plant 3 . The pollen dispersed by wind reaches the nucellar surface of the ovule and the germinating ones produce pollen tubes which in turn penetrate the nucellar region and subsequently deliver the male gametes into the archegonial chamber. Aborted ovules shrink and change colour to black (Image 2e). The fertilized ovules begin development immediately but slowly; the new leaves emerge from the center of sporophylls as soon as the ovules are fertilized (Image 2c), grow well during the rainy season and fall off during late winter by which time the seeds begin to mature. The developing seeds bulge out gradually through the gaps between sporophylls (Image 2d). Seed set is $57.77 \%$ in plant 1, 36.94\% in plant 2 and nil in plant 3. Seeds are flattened, sub-globose, 25-38 mm long, 20-24 $\mathrm{mm}$ wide. The seed coat consists of four layers, the fleshy sarcotesta yellow to brown, smooth sclerotesta, a thick layer of spongy tissue and a thin membranous jacket enclosing the female gametophyte tissue. The embryo is white, cellular and the upper region elongates into suspensor. The sarcotesta eventually becomes wrinkled and at this stage seeds fall to the ground for dispersal. The decomposition of sarcotesta takes place naturally exposing the sclerotesta to enable seed germination.

C. circinalis also reproduces by bulbils, a mode of asexual reproduction. Bulbils are offshoots of the stem and are produced during the rainy season. Scores of bulbils arise from the upper as well as the lower part of the stem of only male plants (Image 2f). Some bulbils germinate on the stem and add new shoots (Image 2 $\mathrm{g}, \mathrm{h})$ while some others germinate and produce new plants after detachment. The success rate of bulbils to produce new shoots or plants is $25 \%$.

\section{Discussion}

C. circinalis shows leaf flushing event after the maturation of cones of both sexes. The leaf flushing activity in coned plants appears to be an inevitable and essential process to gain the lost energy in both sexes and also to supply the photosynthate for the growing seeds in female plants. The leafless state of plants during the coning phase appears to be an evolved process for effective pollen dispersal by wind for maximizing seed set in female plants. The sex of the plant is identifiable only during the coning phase. Newell (1983) also stated that the plants can be sexed only during the coning phase in cycads. Tang (1987) reported that in cycads, male and female cones number from one to several per plant. In C. circinalis, the number of male cones is proportionate to the number of off-shoots per plant and the off-shoots appear to be a result of the growth of bulbils on the plant itself; while female plants seem to produce a single cone due to lack of off-shoots which seem to be related to the bulbil mode of asexual reproduction. Asexual 

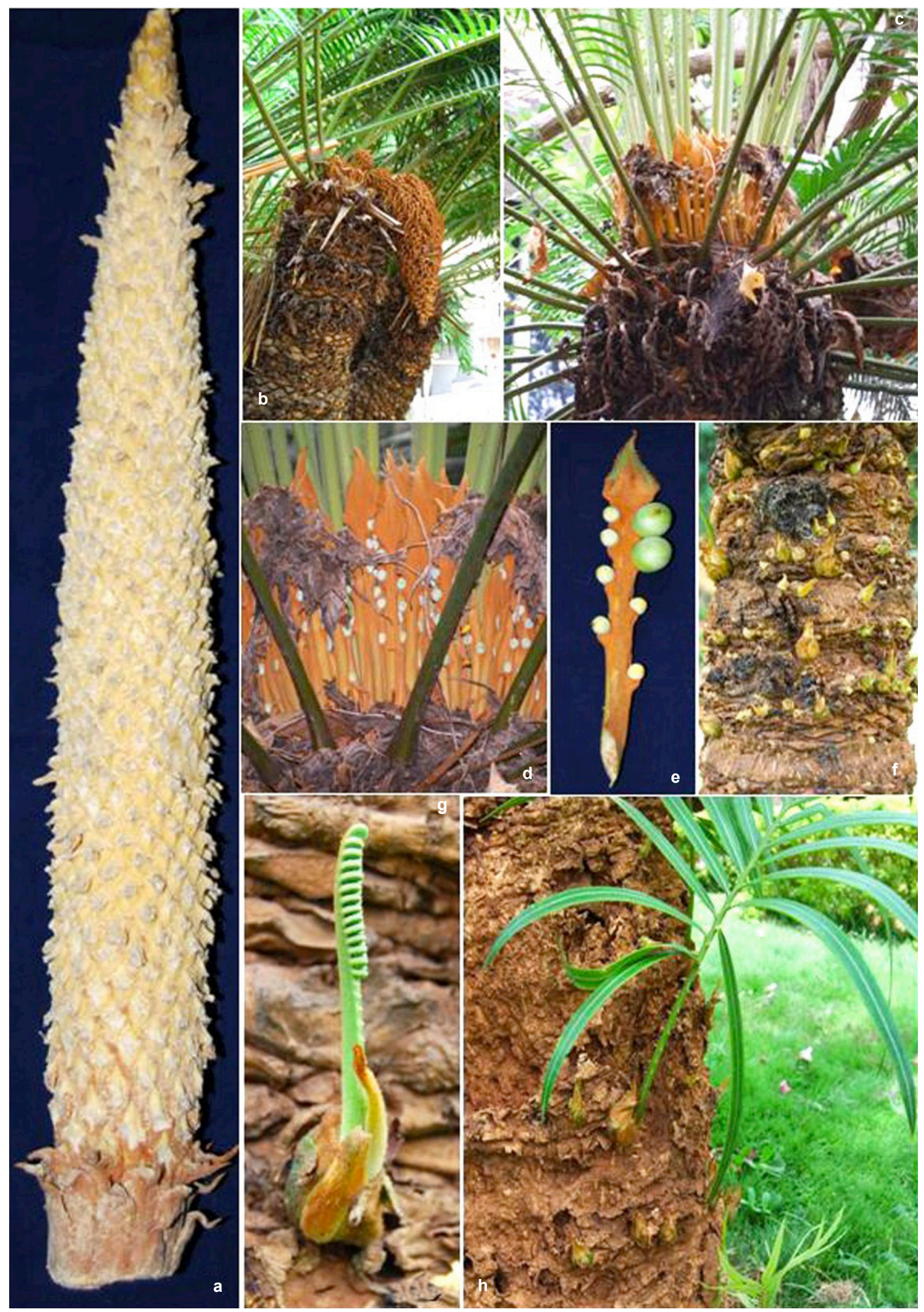

Image 2. Cycas circinalis

a - Male cone axis without any insect breeding; $b$ - Dead bent male cone and leaf flushing in male plant; $\mathrm{c}$ - Leaf flushing from the center of female cone after fertilization; $d$ - Seeds; $e$ - Aborterd ovules and seeds; $f$ - Bulbil production from the stem; $g$ - Bulbil germination; $h$ - New plant from bulbil right on the stem; it subsequently produces a new branch if not detached. 
reproduction has not been evidenced in the female plants observed in this study.

PublishedreportsindicatethatC.panzhihuaensis and C. seemanni are pollinated by wind and beetles (Wang et al. 1997; Keppel 2002); C. rumphii, C. thouarsii and C. media by beetles (Vorster 1995; Norstog \& Nicholls 1997); and C. revoluta primarily by beetles (Kono $\&$ Tobe 2007). Further, thermogenesis and odour production occur during the process of maturation of cones of both sexes in C. rumphii, C. thouarsii and C. revoluta; the odour attracts beetles in both sexes and the beetles visiting the cones effect pollination (Vorster 1995). In C. circinalis, heat production is not very significant and also odour emission is not strong enough to attract insects. Insect activity on both sexes of the plant is absent during coning phase suggesting that the plant is not entomophilous. Proctor et al. (1996) stated that anemophilous species produce typically non-sticky pollen grains that disperse singly and easily. In C. circinalis, the male cones produce huge amounts of light, dry and powdery pollen grains which disperse singly and easily into the air. The pollen quantity increases further with more than one cone produced in some male plants. Jolivet (1998) also stated that a male cone of $C$. circinalis produces enormous quantities of pollen, up to $100 \mathrm{cucm}$. The meteorological conditions for airborne pollen transport are optimal during the coning season of the plant and hence anemophily becomes highly effective. These findings are in agreement with Faegri \& van der Pijl (1979) and Proctor et al. (1996) who stated that genuinely anemophilous plants are characterized by mechanisms to ensure that the pollination phase is perfectly timed so that the pollination event is initiated when meteorological conditions for airborne pollen transport are optimal. Seed set in female cones in the total absence of insects substantiates the role of wind in pollination. It also shows that airborne pollen penetrates well into the female cone although it slightly exposes the ovules. Niklas \& Norstog (1984) reported that $C$. circinalis is pollinated exclusively by wind. Further, they suggested that pollination may have two phases here: the transport of wind-borne pollen grains to megasporophylls and then the subsequent transport of adhering pollen to ovules by water and/ or wind. Stevenson et al. (2009) also mentioned that pollen blown onto the blades of erect megasporophylls might be washed down to the ovules by dew or rain.
In this study, $C$. circinalis with coning phase during the dry season does not experience receipt of water, dew or rain and hence, the two pollination phases are exclusively a function of wind activity.

In Cycads, the seeds usually have brightly coloured sarcotesta, and attract a variety of birds and mammals. These animals feed on the fleshy sarcotesta and disperse the seeds which are protected by a hard sclerotesta (Schneider et al. 2002). C. circinalis seeds with lemon to yellow coloured sarcotesta do not attract any animal class although various bird species are a common sight in the study area. Fallen seeds remain undisturbed. Dehgan \& Yuen (1983) reported that seed coat is four-layered in C. rumphii and $C$. thouarsii; it consists of sarcotesta, sclerotesta, a thick layer of spongy tissue and a thin membranous jacket enclosing the female gametophyte tissue; the spongy layer is important to cause flotation in water for seed dispersal. In C. circinalis also, the seed coat is fourlayered and the layer of spongy tissue seems to be important to cause floatation in water for dispersal. Seeds fall to the ground during late winter and may be washed down to other places by rain water during the rainy season.

C. circinalis also reproduces asexually by bulbils during rainy season. Since it is asexual reproduction, bulbils produce new plants of the same sex from which they are produced. In this study, only male plants have been found to produce bulbils. After detachment, the germinating bulbils form only male plants. Further, some bulbils germinate on the mother plant itself and add new shoots, each of which produces a crown of new leaves subsequently. Each additional shoot takes participation in cone production and hence, it seems to be highly advantageous for the species to assure pollen supply to most of the ovules, if not to all in female plants in order to achieve optimal seed set. Further studies on female plants elsewhere, especially in their natural areas are required to confirm that female plants do not reproduce by the asexual mode of reproduction.

\section{REFERENCES}

Dafni, A., P.G. Kevan \& B.C. Husband (2005). Practical Pollination Biology. Enviroquest, Ltd., Cambridge, 590pp.

Dehgan, B. \& C.K.K.H. Yuen (1983). Seed morphology in relation to dispersal, evolution, and propagation of Cycas 
L. Botanical Gazette 144: 412-418.

Faegri, K. \& L. van der Pijl (1979). The Principles of Pollination Ecology. Pergamon Press, Oxford, 244pp.

Hill, K.D. (1995). The genus Cycas (Cycadaceae) in the Indian region, with notes on the application and typification of the name Cycas circinalis. Taxon 44: 23-31.

Hill, K.D., C.J. Chen \& P.K. Loc (2003). Regional Overview: Asia. Chapter 5, pp. 25-30, In: Donaldson, J. (ed.). Cycads. Status Survey and Conservation Action Plan. IUCN/SSC Cycad Specialist Group, IUCN-The World Conservation Union, Cambridge, UK.

Jolivet, P. (1998). Jurassic Park ou les Coleopteres des cycadales. Le Coleopteriste 33: 77-85.

Keppel, G. (2002). Notes on the Natural History of Cycas seemannii (Cycadaceae). South Pacific Journal of Natural Science 19: 35-41.

Kono, M. \& H. Tobe (2007). Is Cycas revoluta (Cycadaceae) wind- or insect-pollinated? American Journal of Botany 94: 847-855.

Lindstrom, A.J. \& K.D. Hill (2007). The genus Cycas (Cycadaceae) in India. Telopea 11(4): 463-488.

Lowry, O.H., N.J. Rosebrough, A.L. Farr \& R.J. Randall (1951). Protein measurement with the folin phenol reagent. Journal of Biological Chemistry 193: 265-275.

Newell, S.J. (1983). Reproduction in a natural population of cycads (Zamia pumila L.) in Puerto Rico. Bulletin of the Torrey Botanical Club 110: 464-473.

Niklas, K.J. \& K. Norstog (1984). Aerodynamics and pollen grain depositional patterns on Cycad megastrobili: implications on the reproduction of three cycad genera (Cycas, Dioon and Zamia). Botanical Gazette 145: 92104.
Norstog, K.J. \& K.J. Nicholls (1997). The Biology of the Cycads. Cornell University Press, Ithaca, New York, 363pp.

Proctor, M., P. Yeo \& A. Lack (1996). The Natural History of Pollination. Harper Collins Publishers, London, 479pp.

Rao, R.S. \& S.H. Sreeramulu (1986). Flora of Srikakulam District, Andhra Pradesh, India, Meerut University, Meerut, 640pp.

Reddy, C.S., K.S. Rao, C. Pattanaik, K.N. Reddy \& V.S. Raju (2007). Cycas sphaerica Roxb.: A little known endemic species from Eastern Ghats, India. Journal of Plant Sciences 2: 362-365.

Schneider, D., M. Wink, F. Sporer \& P. Lounibos (2002). Cycads: their evolution, toxins, herbivores and insect pollinators. Naturwissenschaften 89: 281-294.

Singh, R. (1993). The Indian Cycas in the field. Cycad Newsletter 16: 2-3.

Stevenson, D.W.M., K.J. Norstog \& P.K.S. Fawcett (2009). Cycad Biology: Pollination biology of Cycads. Virtual Cycad Encyclopedia, Palm \& Cycad Societies of Florida, USA, 513pp.

Tang, W. (1987). Heat production in cycad cones. Botanical Gazette 148: 165-174.

Varghese, A., V. Krishnamurthy, R. Garnesan \& K. Manu (2009). Cycas circinalis. In: IUCN 2010. IUCN Red List of Threatened Species. Version 2010.4. <www.iucnredlist. org $>$. Downloaded on 06 January 2011.

Vorster, P. (1995). Comments on Cycas revoluta. Encephalartos 42: 25-26.

Wang, Q., C.L. Li, S.Y. Yang, R. Huang \& F.L. Chen (1997). Pollination biology of Cycas panzhihuaensis L. Zhou et. and S.Y. Yang. Acta Botanica Sinica 39: 156-163. 